\title{
A Political Economy Analysis of Public Spending Distribution for Disaster Risk Reduction in Bangladesh
}

\author{
Shafiqul Islam ${ }^{1}$, Cordia Chu ${ }^{2}$, James C. R. Smart ${ }^{3}$
}

\begin{abstract}
Bangladesh is one of the resource-scarce countries most vulnerable to climate-related disasters, particularly flood and cyclone. Based on the semi-structured in-depth interviews of 38 stakeholders and literature review, this study examined the public spending distribution process in DRR. This paper demonstrates how the processes of political economy- enclosure, exclusion, encroachment, and entrenchment occurs in the Disaster Risk Reduction (DRR) efforts of Department of Disaster Management (DDM), particularly the distribution of flood shelters. Enclosure occurs when DRR projects are allocated to less vulnerable areas or broaden the influence of dominant actors into the public spending. Exclusion happens when DRR efforts reduce vulnerable people's access to public funds or marginalize disadvantaged stakeholder in decision-making process. Encroachment occurs when the distribution of DRR projects and selection of location and issues increase the environmental hazards or lead to other forms of disaster risk. Entrenchment happens when DRR projects aggravate the injustice or increase the grabbing of resources by the elites and increase inequality a community. This research explored that exclusionary forms of fund distribution of DRR happen locally and nationally. DRR related distribution have encroached through DRR project distribution without discussing local needs. Most severely, DRR related unequal distribution have entrenched social class making the backward communities vulnerable to climate-related disasters. Influencing practitioners of DRR need to take necessary actions to eliminate the potential risks from the processes of enclosure, exclusion, encroachment, and entrenchment happens in DRR related project fund allocations.
\end{abstract}

Keywords: Bangladesh, Disaster Risk Reduction, Fund Distribution, Political Economy

\section{Introduction}

DRR is defined as the concept and practice of reducing disaster risk through systematic planning and timely efforts to manage the causal factors of disasters considering the vulnerability of a place and local context (UNISDR, 2016). Effective implementation of DRR is therefore necessary for a resource-scarce least developed country like Bangladesh which is particularly vulnerable to disaster and climate change(IPCC, 2014). As a developing country, Bangladesh confronts the dilemma of how a balance between development allocation for rapid economic growth (including poverty reduction) and DRR investments with better governance can be achieved. In this context, a political economy angle, specifically, the question of resources allocation for DRR becomes crucial. Bangladesh is an appropriate and interesting case study in this context.

Despite many successes in dealing with disasters, Bangladesh faces several challenges surrounding DRR including lack of capacity among actors and institutions (Alam et al., 2011), policy gaps (Choudhury, Uddin, \& Haque, 2018), lack of collaboration, and coordination(B. K. Sovacool, Tan-Mullins, \& Abrahamse, 2018), lack of better 
governance(Bhuiyan, 2015), and inappropriate distribution of scarce fund (Islam, 2014; Mallick, 2014). These DRR challenges can be considered as problems of political economy (DFID, 2009; Mogues, 2015; Purdon, 2015) because they concern the distribution of resources, and interactions among stakeholders(B. K. Sovacool et al., 2018). More research is required for improved understanding of how best to address the challenges in DRR from different perspectives, such as different country settings and sectors. Therefore, the main objective of this study is to explore the challenges in DRR in Bangladesh from a political economy perspective and to explore practices of political economy nexus in DRR in the hope that the existing barriers can be better curbed.

By investigating the political economy of DRR in Bangladesh, this study intends to make two contributions. First, severe consequences of natural hazards can be exacerbated by manmade factors such as socio-political influence, so it is necessary to understand pathways through which these factors affect DRR (B. K. Sovacool, 2017). Existing literature discusses on issues such as assessment of how governments spend less in DRR efforts (Neumayer, Plümper, \& Barthel, 2014), and the interplay of socio-political actors surrounding political ecology and DRR (D'Alisa \& Kallis, 2016). This study aims to enrich this literature by offering a political economy analysis on the distribution of public funds for DRR in Bangladesh by exploring the key political economy process (DFID, 2009; B. K. Sovacool et al., 2018; Williams, 2011) in DRR initiatives.

Second, existing literature related to DRR centres around vulnerability mapping and guiding future DRR strategies (Kato, 2010; Mitchell T, Reinhard Mechler, \& Harris, 2012; Prabhakar, Srinivasan, \& Shaw, 2009). DRR initiatives and efforts may lead to competition among influencing actors, and these actors might turn the efforts to achieve their own political and economic benefits (B. K. Sovacool, 2017). Therefore, this study aims to examine the empirical political and economic process and to explore how these issues facilitate or hinder the effective public fund distribution for DRR projects in Bangladesh.

Based on a mix of original interviews, a literature review, official documents of DRR related fund distribution, this article explores the local process of DRR related distributions and identified whether the presence of enclosure, exclusion, encroachment and entrenchment in DRR in Bangladesh. This paper explores how DRR efforts can be affected by four cross-connecting political economy processes that work in reality. Enclosure means when public funds found in the hands of influential elites and they use for supporting own supporters for vested interest. Exclusion happens when DRR powerful stakeholders use the state mechanism to remove or displace the community who should have received the benefits. Encroachment means when DRR projects degrade environment instead of improving. Entrenchment refers to when DRR efforts deteriorate social or economic inequality.

\section{Presenting a Conceptual Framework for Political Economy Analysis of this study}

Literatures identifies three major varieties of political economy analysis a) macro-level country analysis:- to enhance understanding of the common sensible features to country, context and broad social, political and economic environment; b) 
sector-level analysis:- to determine the challenges and opportunities to effective delivery of desired outcomes within particular sectors like DRR and CCA; and c) problem-driven analysis:- geared to comprehend, if possible to resolve a specific problem at the field level policy making and project implementation like financing (DFID, 2009; Serrat, 2017). This study will focus on the last two, around the sectors of interest- DRR, in the least developed country setting- Bangladesh.

Although the political economy covers a diverse range of issues, this study mainly focuses on the power and interest of influential actors, public fund distribution mechanism, and decision maker's interactions with a relevant group of stakeholders (DFID, 2009; Purdon, 2015; B. Sovacool \& Linnér, 2015). These key elements shape the efficiency and effectiveness of DRR efforts. Moreover, political economy analysis has been shown to be a powerful tool for improving the effectiveness of development initiatives more broadly (DFID, 2009). Combining the as usual dealing of both politics and economics, political economy analysis deals with how power and resources are transferred, shared and competed in the different groups connecting to DRR and CCA. (Alam et al., 2011). The profound analysis is underneath the formal structures to explore the underlying interests, incentives, and institutions that intensify or reduce changes in climate-related efforts (Mogues, 2015). Therefore, this paper suggests that a political economy analysis will realise the practical incidences of the in-depth of policy making and implementation processes of DRR (de Leon \& Pittock, 2016). The political economy analysis will explore the power struggles and contesting claims over scarce funding (Alam et al., 2011). The literature claimed (Cannon, Twigg, \& Rowell, 2003; Hewitt, 1995; Wisner, Blaikie, Cannon, \& Davis, 2003) that stakeholder attitude and works in relation to DRR are determined by social, economic and political drivers. Issues surrounding selection and distribution of resources also come out: who selects the location and beneficiaries, who are not allowed to select, and how are selection discussed? (Kelman \& Gaillard, 2010). Are the powerful institutions, structures, and mechanisms, which direct the selection process the same as those who in a strong position and in a vulnerable situation? Thus, a key research opportunity is to explore how the interests of key actors influences funding mechanism surrounding DRR.

Synthesizing from four inter-connected disciplines- political economy, political ecology, environmental justice, and development studies, B. K. Sovacool, Linnér, and Goodsite (2015) has identified four political economy processes- enclosure, exclusion, encroachment, and entrenchment. Our study is mainly grounded on this typology of political economy processes. The summary of the process is in Table-1.

Table 1: Process of Enclosure, Exclusion, Encroachment and Entrenchment. (Sovacool et al., 2015)

\begin{tabular}{|l|l|l|}
\hline Process & Description & Sub-processes \\
\hline Enclosure & $\begin{array}{l}\text { Grabbing control } \\
\text { over resources }\end{array}$ & $\begin{array}{l}\text { Centralised power, concentrated authority, privatisation, } \\
\text { Bureaucratic red-tape, } \\
\text { Grabbing the funding mechanism }\end{array}$ \\
\hline Exclusion & $\begin{array}{l}\text { Reject, deprecate } \\
\text { Stakeholders }\end{array}$ & disfavour, extracting resources from the part of distressed, tyranny \\
\hline Encroachment & $\begin{array}{l}\text { Damaging the } \\
\text { Environment }\end{array}$ & $\begin{array}{l}\text { Making public goods into like a business product, servitude, } \\
\text { enslavement, forum shopping }\end{array}$ \\
\hline Entrenchment & aggravate social & Domination of powerful elites, advantage seeking, Comparative \\
\hline
\end{tabular}


\begin{tabular}{l|l} 
Inequality & advantage, elite game.
\end{tabular}

The enclosure may happen when a DRR project distribute a public fund with the hand of influential stakeholders who use them for his own social or political benefit (B. K. Sovacool et al., 2015). It is relevant to the actors and institutions who aggravate their power and authority over local community or areas from which they can receive rents (B. K. Sovacool, 2016). In other words, the enclosure may happen in an invisible way for immaterial issues such as power and sovereignty, or in a visible way for material issues such as money or resource distribution.

Exclusion may arise at the time of the occurrence of the enclosure (Heynen \& Robbins, 2005) and it means when a DRR project includes an influential group, it excludes another vulnerable group. This means it excludes or removes a particular vulnerable groups or reduce their accessibility to benefits maintaining equity, equality, and justice. This kinds of processes of exclusion worsen the situation enable the powerful elites to appropriate or consolidate resources using state mechanisms. (B. K. Sovacool et al., 2015), private enterprises, or social dominants (Forsyth, 2004).

Encroachment occurs when DRR projects increase the environmental pollutions, leads to degraded ecosystem provision, or make obstacles regarding proper protection of biodiversity conservation zones such as protected areas and national parks $(\mathrm{B} . \mathrm{K}$. Sovacool et al., 2015). Although researches demonstrated how the process of the efforts for environmental sustainability themselves can encroach upon vulnerable groups and enhance capitalist agendas (Bryant, 1998; Igoe, Neves, \& Brockington, 2010; Peluso \& Lund, 2011), less importance is found on how hegemonic DRR projects can degrade the environment. For example, making a dam or relocating people without properly assessing the flood level can create another hazardous loss. (Brockington \& Igoe, 2006).

Entrenchment occurs when inequality is increased by further assisting the influential elites to concentrate wealth within a community or transferring risk (B. K. Sovacool, 2018). Economic entrenchment may happen when wealthier people receive the transfer of public funds and take advantage over the vulnerable groups (B. K. Sovacool, 2017). Injustice and unequal distribution make the vulnerable group poorer and make advantaged people richer by the process of vested interest seeking behaviours of opportunity seekers at power. (Folke et al., 2004; Little, Smith, Cellarius, Coppock, \& Barrett, 2001). Entrenchment, in other words, works hiddenly and maintains, often deteriorate present power struggles within or between stakeholders (Christens, Hanlin, \& Speer, 2007).

Using the above typology of a political economy conceptual framework, this study explored how DRR efforts such as establishing flood centres have gone through the political economy process, especially, at the time of distribution of DRR related resources among various locations and beneficiaries.

\section{Case Selection, and Research Methodology}

\subsection{Study Setting}

The study undertook Bangladesh as a case study because of its extreme vulnerability to disaster and climate-related impacts such as flood and cyclone. Major parts of Bangladesh stand in the delta of three of the largest rivers in the world: the 
Ganges, the Brahmaputra, and the Meghna (GBM) (Mirza, 2002). Bangladesh is at the vulnerable situation not only of flooding but also affected from the melting of the Indian and Nepali Himalayan glaciers; and the rainwaters from Indian hills flowing to lower districts like Sunamganj. In addition, climate change is contributing to increased rain during the monsoon season. Further complicating matter is that the configuration of the land of Bangladesh is low and flat. More than $75 \%$ of the Bangladesh infrastructure is less than 5 metres above sea level and vulnerable to flash flooding and rainwater flooding in lowland areas (ClimateChangeCell, 2009). Mirza (2002) documented four types of flooding in Bangladesh- flash floods; riverine floods, rain floods, storm surge floods caused by climate change. Bangladesh is one of those 10 countries in the world most vulnerable to climate change-induced natural calamities (Germanwatch, 2014). Flood took thousands of lives and huge resources in 1974, 1988, 1998, 2004 and 2007 in Bangladesh (Government of Bangladesh, 2014). Cyclones struck in 1970, 1991, 2007 and 2009 and killed 364,000, 136,000, 3,363 and 190 respectively(ADRC, 2005).

In Bangladesh, there are many initiatives, efforts, projects and programs addressing DRR. Under the DRR umbrella, as a case, this study focusses on programs named 'Construction of flood shelters in flood-prone areas' implemented by Department of Disaster Management (DDM), Ministry of Disaster Management and Relief.

\subsection{Construction of flood shelter in flood-prone areas}

As per the guidance of Hyogo framework, the Disaster Management Act, Poverty Reduction Strategy Papers, the $6^{\text {th }}$ five-year plan, the DDM of Ministry of the Disaster Management and Relief has implemented a program named 'Construction of flood shelters in flood-prone areas' since 2008. So far, 99 shelters have been built and 173 more shelters are being implemented in different districts. These shelters help floodaffected people to take shelter with their assets, and livestock during times of flood (DDM, 2016). This research focuses on why and how the locations of these shelters are determined, which necessarily also determines who obtains a benefit from these DDM investments. It explored the process of the distribution and the implications turned out.

\subsection{Methods}

A total of 38 in-depth interviews (IDIs) were conducted with stakeholders in DRR in Bangladesh (Table-2). In-depth interviews (IDIs) are undertaken to have a detailed understanding of the sectors of DRR from the perception, experiences and opinions of stakeholders. The study also recruited the central decision-makers, officials from national and international organizations depending on their connection to DRR using a snowball-sampling method(Noy, 2008). The study was conducted in Dhaka, the Sunamganj districts and the Shalla subdistricts of Bangladesh. From Dhaka, the study conducted an in-depth interview with key stakeholders of DRR including Ministry of Disaster Management and Relief, Ministry of Environment and forest, Department of Disaster Management, Department of Environment, Ministry of Finance, Ministry of Planning, WB, UNDP, research institutions, universities and others. Sunamganj district is one of the most flood-affected districts in Bangladesh and Shalla is one of the most flood-affected, remote and vulnerable Upazila of Sunamganj District (BangladeshBureauofStatistics, 2015). At district and sub-district level, IDIs are 
conducted with, community leaders, local government representatives, local district and sub-district level officials, and local politicians.

Table 2: Distribution of in-depth interviews (IDIs) participants.

\begin{tabular}{|c|c|c|c|c|}
\hline Participants & $\begin{array}{c}\text { Ministry } \\
\text { (Top-level) }\end{array}$ & $\begin{array}{c}\text { Ministry } \\
\text { (mid-level) }\end{array}$ & $\begin{array}{c}\text { Local } \\
\text { (district and subdistrict) }\end{array}$ & Total \\
\hline Decision-makers and Government officials & 06 & 08 & 05 & 19 \\
\hline Political leaders and Public Representatives & & & & 06 \\
\hline Community leaders & & & & 03 \\
\hline International organizations & & & & 04 \\
\hline Academic and consultant & & & & 04 \\
\hline Journalist & & & & 02 \\
\hline Total & & & & 38 \\
\hline
\end{tabular}

IDI data collection took place from April 2016 to April 2018. This study developed an open-ended topic guide in English and translated into Bengali. In addition, the researcher pretested the interview guides and adjusted as per the requirements from the field testing before starting the data collection. Stakeholders were assured that they would remain anonymous. The researcher assured the participants that their identity will not be published in any form. All interviews were conducted in Bengali. Most interviews lasted 30 minutes and one hour. Then all interviews were digitally recorded, and detailed field notes were taken simultaneously during each interview. The principal researcher translated all interview recordings and transcribed them into text documents. This study received ethical approval granted by the Griffith University Human Research Ethics Committee (2017/446).

The study used a qualitative thematic method to analyse the IDI transcripts. First, the researcher read and reread the transcripts and achieved the familiarization with the data. After familiarization, intercoder reliability was achieved by independent coding. Initially, from the description of the texts, a general code list was developed for data analysis. Based on the codes, themes and subthemes were identified for analysis and the analysis was adapted and finalized based on the findings and emergent themes as part of the iterative process of qualitative data analysis. Data were managed by using NVIVO software 11 version.

\section{Result}

This section consists of two parts. In the first part, based on official documents of fund transfer, we have shown what happened in reality and practice surrounding DRR efforts especially the distribution of flood shelters among all districts of Bangladesh, and the process of selection of beneficiary and location. In the second part, based on Indepth Interviews (IDIs), we have explored how the process of distribution occurred, how decisions are made and what implications that could make.

\subsection{Distribution of flood shelters: normative guidelines versus reality.}

Chief researcher of this study has collected the official documents of these 273 
shelters implemented by DDM. Inspecting the list of 273 flood shelters and visiting some of the rural shelters, we have scrutinized the content of the list, the name and title of the projects, compared the location and issues of the projects in different districts. As per the disaster management Acts, guidelines, rules and policies, the allocations must be based on the population of the area, size of the area and poverty rate of the area. These three issues are mandatory determinants of deciding the amount of allocation of one district. Normatively, it is told that the flood-prone area will receive priority.

However, Figure-1 drawn from official allocation-information shows that the highest populated districts, the highest poverty rated district, the highest area sized districts and the most flood-affected districts did not receive the highest number of shelters it's starting 2008 to 2017. Some districts such as Kurigram received a reasonable portion of total allocations, whereas some districts such as Sunamganj (highest disaster-affected) did not receive reasonable allocations. Similarly, Kishoreganj district received the highest number of shelters ignoring all the mandatory criteria mentioned above. Some discrepancies are found in the location selection of the shelters. The existing guidelines and rules are often ignored.

Moreover, the allocation of shelters in terms of location and beneficiaries and engagement scenario suggests that though the funds are intended to allocate to the flood-prone area, there are some deviations occurred. Few unequal and improper allocations are found in comparison to the vulnerable and nonvulnerable area, city and rural area, flood-prone and non-flood prone area. The political influence of the influencing decisionmakers might take place in the process of project approval; location selection and opinions of local people were not considered in designing the project. Implementing agency might limit the disclosure of accurate information to other stakeholders like relevant officials and local government representatives. This leads to the overlapping of projects in the same area/issues.
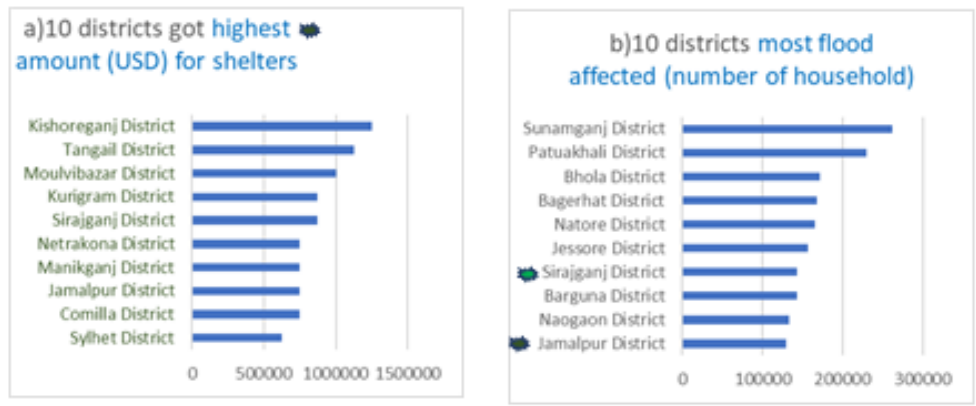

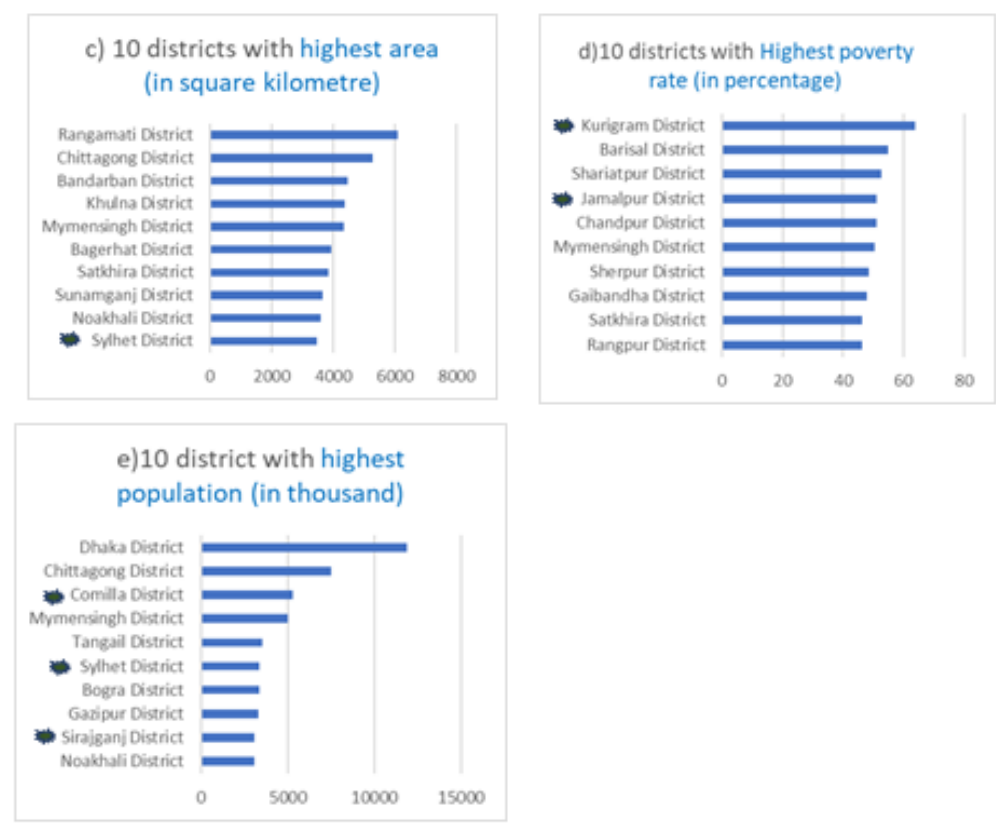

Figure 1: (a) Districts (named in green) received highest number of flood shelters from the project administered by the DDM, compared with districts with (b)highest flood risk, (c) largest area, (d)highest poverty rate, (e) largest population (drawn by author based on the official documents of DDM, and Bangladesh: Disaster-Related Statistics 2015).

This paper also focused how the location, design, features of these shelters are relevant to climate change impact, as Disaster Management Act emphasized the importance of addressing climate change issues in implementing disaster risk reduction initiatives. Because of climate change impacts such as sea-level rise, heavy raining, changing seasons, and temperature increase, the vulnerability of various areas to the disaster has increased severely. The design, layout and the planning of these flood centres should have concentrated on the changing climate change impacts. In reality, there are some deviations identified. The design of the flood centres is similar for low land area, hill area, and coastal area. It should have been different based on local needs. Therefore, some of the flood centres sank in the last year flood. Moreover, in some cases, though the local people urged for making more highness of the shelters, because of resource shortage it could not be implemented so. However, some issues prove that the issues of climate change impact were taken into consideration while the design of the shelters planned. For example, shelters' highness was measured based on the water level of the last couple of biggest floods, the solar panel was installed on the roof of the shelters, the ground floor was designed for the live stocks accommodation during shelters.

The reasons for this kind of inappropriate allocations are found from the in-depth interview of the stakeholders and discussed in the next sections. 


\subsection{The presence of enclosure, exclusion, encroachment, and entrenchment in DRR efforts: Stakeholder's opinion}

We have found that in many cases, the four processes emerge as a result of how DRR projects are designed and implemented especially through the process of selection of location and beneficiaries of DRR projects. Here we focus on examples and experiences from the stakeholder's interview to illustrate how the processes work.

\subsubsection{Enclosure}

The following statements demonstrate the process of enclosure. Although normative rules are there that the distribution of DRR projects will be distributed based on population, poverty rate, area size, and disaster effect and vulnerability of a particular location, IDIs claimed that sometimes some other factors influence this distribution process. Influential elites who are involved in this process do play a greater role than the issues of the disaster-affected area. One local leader said:

"About big projects, local Member of Parliament does the distribution through the political leaders. Though the implementation is through government offices officially in papers, in reality, he or she does the division based on the local leader's interest and demands to have the electoral benefits".

The documents show that disaster-related funds and projects are distributed by disaster management committees in Bangladesh. Consequently, the committee members influence funding allocations. For example, nationally and locally, the disaster management committee's members make a decision over fund allocation and project distribution. One researcher and official said:

"Some ministers and bureaucrats are the members of the National Disaster Management Committee and District and Subdistrict level disaster management committees. Although, the distribution should have been to the regions that are most vulnerable and most in needs, many projects are distributed in their own choices."

From the investigation of the process it is also found that as per policy, these shelters should be in the flood-prone area. Ministry decides which districts and subdistricts will receive it. Ministry sends the letters to the local offices. They consult with local Member of Parliament and representatives then the location is selected. Although the circulars say that it should be in the flood-prone area, in reality, sometimes it happens that ministers influence the selection of district and subdistricts.

The enclosure of influential locals happened in this manner in many cases and the actual aims for DRR are not achieved as per the visionary plans.

\subsubsection{Exclusion}

The incidences of the process of exclusion can be found from the following statements from IDIs. These processes have affected multiple dimensions of DRR in Bangladesh, ranging from exclusionary form of planning or implementation at the national scale to elite domination at the community scale. The common people and backward people who do not have social power or economic power are often excluded from the decision-making bodies and from the list of beneficiaries. One official from DDM explained:

"Sometimes it happens that local MP and local political and social elites decide and 
influence the distribution of flood shelter to a specific location. When local elites select the location, they sometimes do not consider the community needs or flood affected area; rather they see the interest of local party leaders, next election issue, benefits of own relatives."

These types of practices lead to the exclusion of the vulnerable community from DRR related funding and project benefits.

One district level officer revealed his perspective:

"This district is most flood-affected, we received only three flood shelters whereas some districts less affected from flood received more than ten flood shelters. Lobbying from local and central leaders influences the allocation process and selection of beneficiaries and locations.

The Figure-3 on the distribution of funds also support this statement that the highest disaster-affected districts are not receiving the highest number of flood shelters.

One of the rural local subdistrict leaders shared his view:

"We live in a very rural area; we do not have an education; we do not know the paths where to go; do not know the procedures how to apply; we cannot go to Dhaka; we cannot manage funds. So, we receive fewer allocations than the subdistricts were advanced, educated and aware people live"

In this manner, the vulnerable flood-affected community in need are excluded through the process of distribution by the dominant stakeholders. Literature also confirms similar statements about the exclusion of affected people. The Bangladeshi NAPA and BCCSAP process included economists, scientists, as well as government officials, but not the representatives from the most vulnerable groups (ADRC., 2014; Shamsuddoha, Roberts, Hasemann, \& Roddick, 2013).

\subsubsection{Encroachment}

Following issues exemplify the process of Encroachment. The narratives and experiences of key stakeholders revealed implications and some aspect of encroachmentadverse impact on the environment and local situations. The existing apparatus of the political economy process encourages local leaders and contractors to constructs more visible roads and other infrastructure without considering climate vulnerability or local needs. one community leader connecting to the agricultural sector from a District shared his experience about a project:

"We got this dam project form the Water Development Board (WDB). Actually, this is not our genuine need. We needed excavation of river and canals so that water that comes from India flows smoothly. Otherwise, flash floods will happen. Because of this dam, our houses might be safe but our crops will be submerged by water. How we will live if our only crop paddy washed away? If the excavation of river is accomplished with the same amount of money spent on dam, neither our house nor our crops would have been affected by flash-flood. They did not discuss with us. We have heard that Our MP managed this project from WDB"

One consultant of DDM explains his experience

"In a subdistrict of Chittagong, the local government (third tier) made local level planning and they needed a damn cum road. So they asked the Ministry of Disaster Management and Relief to receive the fund and they were also trying with own fund. In 
the meantime, WDB implemented a big dam crossing the subdistrict by a river. But it was not consulted with the local community, so the location selection was different from the local level planning. And this dam of WDB is creating a huge waterlog which jeopardizing the livelihood of the people of some of the areas and their crops. Therefore, this lack of coordination brings environmental hazards instead of benefits "

When the projects are not planned with proper ground work considering probable risks, the effectiveness of a project may result in vein. If the selection of location and beneficiaries is not based on vulnerability, it may bring adverse consequences to the affected people who are forced to migrate from their living places.

The encroachment occurs in this way and degrade the environment or aggravate the disaster impact leading the community to a more vulnerable situation.

\subsubsection{Entrenchment}

Stakeholders have acknowledged the presence of entrenchment based on political ideologies, social class and religious belief surrounding the distribution of DRR projects. Social and cultural norms work informally (Helmke \& Levitsky, 2004). When DRR project funding is distributed, blood connections, nepotism, cultural affiliation etc definitely influence the outcomes (Alam et al., 2011). One key member of Upazila Council (the second tier of local government) who is also a key member of an Upazila disaster management committee said,

"Sometimes if the people of the needy location, which is mostly flood affected, have different political belief, not supportive of the party in power, they do not receive the flood shelters. This sometimes happens in Bangladesh, whatever political party comes in power".

On the implementation side, differences in religious beliefs can lead to inequalities in fund distribution for DRR. When religious beliefs of the leaders and community coincide, the funding allocation is typically higher. One local level official shared his opinion from twenty years' experience in disaster management that the selection of beneficiaries and selection of location are significantly influenced by religious ideology, in some cases.

"If the local leaders, public representatives and Member of Parliament is from a particular religious group, the community of that particular religious group receive priority. For example, if the leaders are from the Hindu religion, the temples receive more funds, if the leaders are Muslim, mosques receive more funds."

Moreover, the social and economic class also matters. The area where more educated and influential people live, receive more public funds because they have good connections with high-ups. One Union Council Chairman expressed his views.

"A district received 22 flood shelters as an influential minister is from that district and a district received 18 flood shelters as the influential minister is from that district. Whereas, we received less- only three shelters, although our district is the most disaster-affected district. It is the matter of ministry officials and decision-makers. We do not have control over it."

Inequality based on religious and political believes found in some instances DRR related fund distribution such as flood shelter distributions.

\section{Discussion, Policy Implication and Recommendation}


This research explored that inclusion of influential stakeholders happens at the time distribution of DRR funds; exclusionary forms of fund distribution of DRR exist at both the national and local scales, and DRR related allocations have encroached through the low land areas development project without consulting local needs. Most severely, DRR related unequal allocations have entrenched social class trapping the backward communities vulnerable to climate-related disasters. The four political economy processes-enclosure, exclusion, encroachment, and entrenchment are also found in the study of global climate change and contaminants (Sanderson \& Goodsite, 2015), climate adaptation initiatives (B. K. Sovacool et al., 2015), climate change adaptation projects in LDCF(B. K. Sovacool, Linnér, \& Klein, 2016), climate change adaptation efforts in Bangladesh (B. K. Sovacool, 2018), This study has explored these practices and processes in many forms in the DRR related funding distribution in Bangladesh.

The political economy processes of DRR may sometimes derail or direct the outcome of the project and process to the favour of influential stakeholders. However, that does not mean that all projects completely reduce or remove the benefits of DRR projects. Although this study raises some criticisms, some of the projects are found really aimed at the goals. Therefore, throughout the works, improved learning need to be taken so that vulnerable are helped and facilities of the projects are made visible and fruitful to the distress people who are in need. Policy makers and practitioners of DRR should be more cautious and active to remove the potential anomalies of the projects and to reduce the processes of enclosure, exclusion, encroachment, and entrenchment. In brief, in each of the steps of project planning and implementation DRR practitioners should ask "DRR for whom?"

Keeping this in mind, DRR efforts should be aimed to reduce the grave threats to vulnerable groups. Moreover, due to its political economy processes, most of the DRR efforts undertaken in Bangladesh may require further DRR efforts. Therefore, the implication of the findings of the study is wide. These political economy processes will incur a high cost, and inefficiencies in maintenance, resettlement, relocation, and reimplementation. Furthermore, if sea level rises over the height of the present level, they could cause a severe loss from flood or cyclone behind them. Bangladeshi planners and practitioners should no more avoid the larger social and political space in which influential decision-makers work.

The first recommendation is to make strict rules to include the vulnerable community in the planning and implementation process so that they can contribute easily without any harassment or manipulation. A project should not be designed and planned based on the interests of the contractors, and local influential who often try to divest the efforts.

The second recommendation is to confirm enough access to DRR resources for the vulnerable with equity and equality among all social and economic classes. This could be done through the proper implementation of existing rules in which local voice needs to be stipulated. The location and beneficiary should be selected based on vulnerability and the solution should be based on the discussion with local affected people.

The third recommendation is to find best practices and designs and implement them country wide in different emerging DRR projects and practices. For this comparing between projects are necessary to find the best practices and implement them in new 
settings keeping the realities may come

The findings of this study are from a case study of Bangladesh, cautions might need to generalise by other developing countries and to take learning from it. Notwithstanding this limitation, this study argues that planners and practitioners should take note of these processes while they distribute resources for DRR and decide in the selection of location and beneficiaries.

\section{Conclusion}

The political economy of DRR, name the processes of enclosure, exclusion, encroachment, and entrenchment, may reduce or remove the targets and effects by diverting the well-intentioned projects and efforts. The cases of distribution of flood shelters and some other DRR related projects have exhibited these political economy processes. This study demonstrates that social and political conflicts are not separable completely from DRR processes and practices. Even the planners have good intentions, the designs, interventions, implementation will not be able to escape the power struggles that creates the four connected political economy processes- enclosure, exclusion, encroachment, and entrenchment. However, if planners and practitioners are aware of these processes, these can be curved. In every step, they should ask the question DRR for whom?

Although the above suggestions are about policy and practices, this study is considering the presence of social, political and economic factors behind this policy and practices. The study acknowledges the necessity of addressing these factors and managing the trade-offs politically. Optimum paths, balanced institutions, cost-effective mechanisms and a holistic decision-making process needs to be established. They will result in better disaster recovery, ecological resilience, and local sustainable development. This allows the DRR policymakers and practitioners to avail windows of opportunity those cannot be stopped by political economy nexus if the dominant stakeholders involved in DRR work with awareness.

\section{References}

ADRC. (2005). Definition of disaster risk Total disaster risk management: Good practices. Retrieved from http://www.adrc.or.jp/publications/TDRM2005/TDRM_Good_Practices/PDF/PDF2005e/Chapter1 1.2.pdf

ADRC., A. D. R. C. (2014 ). Information on disaster risk reduction of the member countries. Retrieved from http://www.adrc.asia/nationinformation.php?NationCode $=50 \&$ Lang $=$ en \&NationNum $=13$

Alam, K., Shamsuddoha, M., Tanner, T., Sultana, M., Huq, M. J., \& Kabir, S. S. (2011). The Political Economy of Climate Resilient Development Planning in Bangladesh. IDS Bulletin, 42(3), 52-61.

BangladeshBureauofStatistics. (2015). Bangladesh: Disaster Related Statistics 2015, climate change and natural disaster persepective. . Retrieved from http://www.bbs.gov.bd/

Bhuiyan, S. (2015). Adapting to Climate Change in Bangladesh Good Governance Barriers. South Asia Research, 35(3), 349-367.

Brockington, D., \& Igoe, J. (2006). Eviction for conservation: a global overview. Conservation and society, 424-470.

Bryant, R. L. (1998). Power, knowledge and political ecology in the third world: a review. Progress in physical geography, 22(1), 79-94.

Cannon, T., Twigg, J., \& Rowell, J. (2003). Social vulnerability, sustainable livelihoods and disasters. In: London: DFID. 
Choudhury, M.-U.-I., Uddin, M. S., \& Haque, C. E. (2018). "Nature brings us extreme events, some people cause us prolonged sufferings": the role of good governance in building community resilience to natural disasters in Bangladesh. Journal of Environmental Planning and Management, 1-21.

Christens, B. D., Hanlin, C. E., \& Speer, P. W. (2007). Getting the social organism thinking: Strategy for systems change. American journal of community psychology, 39(3-4), 229.

ClimateChangeCell. (2009). Impact assessment of climate change and sea level rise on monsoon flooding. Dhaka: Climate Change Cell, Ministry of Environment and Forests.

D'Alisa, G., \& Kallis, G. (2016). A political ecology of maladaptation: Insights from a Gramscian theory of the State. Global Environmental Change, 38, 230-242.

DDM, D. o. D. M. (2016). Construction of Flood Shelter. Retrieved from http://www.ddm.gov.bd/site/page/2b4dff73-562d-4708-821285507d $22 \mathrm{~d} 0 \mathrm{a} 8 / \% \mathrm{E} 0 \% \mathrm{~A} 6 \% \mathrm{AC} \% \mathrm{E} 0 \% \mathrm{~A} 6 \% \mathrm{~A} 8 \% \mathrm{E} 0 \% \mathrm{~A} 7 \% 8 \mathrm{D} \% \mathrm{E} 0 \% \mathrm{~A} 6 \% \mathrm{AF} \% \mathrm{E} 0 \% \mathrm{~A} 6 \% \mathrm{BE}-$ $\% \mathrm{E} 0 \% \mathrm{~A} 6 \% 86 \% \mathrm{E} 0 \% \mathrm{~A} 6 \% \mathrm{~B} 6 \% \mathrm{E} 0 \% \mathrm{~A} 7 \% 8 \mathrm{D} \% \mathrm{E} 0 \% \mathrm{~A} 6 \% \mathrm{~B} 0 \% \mathrm{E} 0 \% \mathrm{~A} 7 \% 9 \mathrm{~F} \% \mathrm{E} 0 \% \mathrm{~A} 6 \% 95 \% \mathrm{E} 0 \% \mathrm{~A}$ $7 \% 87 \% \mathrm{E} 0 \% \mathrm{~A} 6 \% \mathrm{~A} 8 \% \mathrm{E} 0 \% \mathrm{~A} 7 \% 8 \mathrm{D} \% \mathrm{E} 0 \% \mathrm{~A} 6 \% \mathrm{~A} 6 \% \mathrm{E} 0 \% \mathrm{~A} 7 \% 8 \mathrm{D} \% \mathrm{E} 0 \% \mathrm{~A} 6 \% \mathrm{~B} 0$

de Leon, E., \& Pittock, J. (2016). Integrating climate change adaptation and climate-related disaster riskreduction policy in developing countries: A case study in the Philippines. Climate and Development, 18.

DFID. (2009). Political Economy Analysis How To Note. A DFID Practice Paper. London: Department for International Development.

Folke, C., Carpenter, S., Walker, B., Scheffer, M., Elmqvist, T., Gunderson, L., \& Holling, C. S. (2004). Regime shifts, resilience, and biodiversity in ecosystem management. Annu. Rev. Ecol. Evol. Syst., 35, 557-581.

Forsyth, T. (2004). Critical political ecology: the politics of environmental science: Routledge.

Germanwatch. (2014). Global Climate Risk Index 2014. Retrieved from https://germanwatch.org/en/download/8551.pdf

Government of Bangladesh. (2014). Climate Fiscal Framework. Retrieved from https://info.undp.org/docs/pdc/Documents/BGD/1695\%20ClimateChange FullLayout $\% 2029$ 0914.pdf

Helmke, G., \& Levitsky, S. (2004). Informal institutions and comparative politics: A research agenda. Perspectives on Politics, 2(4), 725-740.

Hewitt, K. (1995). Excluded perspectives in the social construction of disaster. International Journal of Mass

Emergencies and Disasters, 13(3), 317-339.

Heynen, N., \& Robbins, P. (2005). The neoliberalization of nature: Governance, privatization, enclosure and valuation. Capitalism Nature Socialism, 16(1), 5-8.

Igoe, J., Neves, K., \& Brockington, D. (2010). A spectacular eco- tour around the historic bloc: Theorising the convergence of biodiversity conservation and capitalist expansion. Antipode, 42(3), 486-512.

IPCC. (2014). Climate change 2014: synthesis report. Summary for policymakers Retrieved from https://www.ipcc.ch/pdf/assessment-report/ar5/syr/AR5 SYR FINAL SPM.pdf

Islam, M. M. (2014). The Politics of the Public Food Distribution System in Bangladesh: Regime Survival or Promoting Food Security? Journal of Asian and African Studies, 50(6), 702-715. doi:10.1177/0021909614541082

Kato, M. (2010). Disaster risk reduction under the United Nations Framework convention on Climate Change. Climate change adaptation and disaster risk reduction: issues and challenges. Emerald Publication, Bingley, 47-75.

Kelman, I., \& Gaillard, J. C. (2010). Embedding climate change adaptation within disaster risk reduction. Climate change adaptation and disaster risk reduction: Issues and challenges, 4, 23-46.

Little, P. D., Smith, K., Cellarius, B. A., Coppock, D. L., \& Barrett, C. (2001). Avoiding disaster: diversification and risk management among East African herders. Development and Change, 32(3), 401-433.

Mallick, B. (2014). Cyclone shelters and their locational suitability: an empirical analysis from coastal Bangladesh. Disasters, 38(3), 654-671.

Mirza, M. M. Q. (2002). Global warming and changes in the probability of occurrence of floods in Bangladesh and implications. Global Environmental Change, 12(2), 127-138.

Mitchell T, D., Reinhard Mechler, D., \& Harris, K. (2012). Tackling exposure: placing disaster risk management at the heart of national economic and fiscal policy. 
Mogues, T. (2015). Political economy determinants of public spending allocations: A review of theories, and implications for agricultural public investment. European Journal of Development Research, 27(3), 452473.

Neumayer, E., Plümper, T., \& Barthel, F. (2014). The political economy of natural disaster damage. Global Environmental Change, 24, 8-19.

Noy, C. (2008). Sampling knowledge: The hermeneutics of snowball sampling in qualitative research. International Journal of social research methodology, 11(4), 327-344.

Peluso, N. L., \& Lund, C. (2011). New frontiers of land control: Introduction. Journal of Peasant Studies, 38(4), 667-681.

Prabhakar, S., Srinivasan, A., \& Shaw, R. (2009). Climate change and local level disaster risk reduction planning: need, opportunities and challenges. Mitigation and adaptation strategies for global change, 14(1), 7.

Purdon, M. (2015). Advancing Comparative Climate Change Politics: Theory and Method. Global Environmental Politics.

Sanderson, H., \& Goodsite, M. (2015). Global climate change and contaminants. In: Multidisciplinary Digital Publishing Institute.

Serrat, O. (2017). Political economy analysis for development effectiveness. In Knowledge Solutions (pp. 207222): Springer.

Shamsuddoha, M., Roberts, E., Hasemann, A., \& Roddick, S. (2013). Establishing Links between Disaster Risk Reduction and Climate Change Adaptation in the Context of Loss and Damage. In: CPRD.

Sovacool, B., \& Linnér, B.-O. (2015). The political economy of climate change adaptation: Springer.

Sovacool, B. K. (2016). The political ecology and justice of energy. In The Palgrave Handbook of the International Political Economy of Energy (pp. 529-558): Springer.

Sovacool, B. K. (2017). Don't let disaster recovery perpetuate injustice. Nature, 549(7673), 433-433.

Sovacool, B. K. (2018). Bamboo beating bandits: conflict, inequality, and vulnerability in the political ecology of climate change adaptation in Bangladesh. World Development, 102, 183-194.

Sovacool, B. K., Linnér, B.-O., \& Goodsite, M. E. (2015). The political economy of climate adaptation. Nature Climate Change, 5(7), 616-618.

Sovacool, B. K., Linnér, B.-O., \& Klein, R. J. (2016). Climate change adaptation and the Least Developed Countries Fund (LDCF): Qualitative insights from policy implementation in the Asia-Pacific. Climatic Change, 1-18.

Sovacool, B. K., Tan-Mullins, M., \& Abrahamse, W. (2018). Bloated bodies and broken bricks: Power, ecology, and inequality in the political economy of natural disaster recovery. World Development, 110, 243-255.

Williams, G. (2011). Study on disaster risk reduction, decentralization and political economy. Background Paper for the.

Wisner, B., Blaikie, P., Cannon, T., \& Davis, I. (2003). At risk: natural hazards, people's vulnerability and disasters (second ed.): New York. Routledge. 